\title{
Dancing in the Hall
}

\author{
Lisa Schneier ${ }^{1,2}$ iD
}

Received: 18 August 2017/Accepted: 18 January 2018/Published online: 21 February 2018

(C) The Author(s) 2018. This article is an open access publication

\begin{abstract}
Originally written 30 years ago, this paper is an analysis of the central challenge of schooling - that of engaging fully the powers of students' minds in classroom learning. This challenge maintains its relevance today. The work of engaging what John Dewey referred to as students" "inner attention" becomes the focus of an investigation of students' current ideas in a variety of subject matters. This investigation reveals areas in which their ideas diverge from the established curriculum. It uses the methodology of Critical Exploration, which was developed by Eleanor Duckworth as a teaching and research methodology that both reveals learners' ideas and encourages their active creation of meaning. This methodology provides students with rich and complex curriculum materials for their own manipulation; it also provides them the freedom to express, however tentatively, their ideas, to take them seriously, and to follow them through. As a result of these studies of learning, I put forward the view that a significant part of the responsibility for students' alienation from classroom learning lies with a conception of knowledge, often reflected in curriculum, that is too rigid to take their ideas into account. I elaborate this view in an analysis of the aspects of particular subject matters that alienate students if the students are not given adequate ways of entering them. I make the case that these same complexities can be used as compelling invitations into deeper knowledge.
\end{abstract}

Keywords Exploratory learning · Learning · Teaching poetry · Teaching math $\cdot$ Curriculum $\cdot$ Teaching

Lisa Schneier

schneier.lisa@gmail.com

1 Emmanuel College, Boston, MA, USA

2 Harvard Graduate School of Education, Cambridge, MA, USA 
Daniel moves to class-two steps forward, one back, two steps forward, one backbending his knees, shaking his head, moving his lips to an imagined song. Another boy leaps up the steps, taking them three at a time. Leslie stands talking to friends, arms gesturing, face alive with her story. Malcolm runs backwards down the stairs. Juan jumps high to catch some object sent down the hall by a friend. Two boys clasp hands briefly as they pass each other. Marcus and Kendra take long, matching strides, swinging backpacks high. A loud group congregates on the stair landing to meet friends coming up. Carmen walks slowly, looking into faces, her expression intent. Kenneth bounces up and down, earphones thinly concealed by hat and sweater. Stephen slides down a banister, lands gracefully, and beats a rhythm on the wall.

Three minutes in the hall divides the class time in the high school where I teach. It is the frequent, sometimes glaring, sometimes much more subtle change in character between those three minutes and the class time which follows them that is my deepest concern as a teacher. Daniel sits at a table, head down and covered by his arms; a few minutes before he had been dancing in the hall. Carmen, who had earlier given me a vivid and lively description of a movie, standing up in the middle to increase the power of the telling, has, though her head is still up and her eyes still looking, quietly pulled her vitality inward and away. I dread this subtle withdrawal even more than the obvious one of Daniel putting his head down on his desk. At least he is, by that very gesture, still trying to say something. It is the quiet withdrawal-which leaves at best a shallow attention and at worst only its appearance - that is most disturbing and difficult to counter. I am not talking about students' attention to me personally, but rather to some subject matter and to me and each other as we are involved in that subject matter. A statement of John Dewey's captures what I am trying to describe:

As every teacher knows, children have an inner and outer attention. The inner attention is the giving of the mind without reserve or qualification to the subject at hand. It is the first-hand and personal play of mental powers. As such, it is the fundamental condition of mental growth (Dewey, 1904, p. 318).

It was this "giving of the mind" that Carmen showed as she translated her memory of the movie into vivid description. And it was this inner attention that Daniel also displayed in his concentrated, rhythmic movement down the hall.

\section{The Setting}

I teach ninth graders in a high school program designed to help freshmen who are having "academic trouble" in three or more of what are considered the major subject classes - math, science, history, and English. Though my background is in English, I am also responsible for some of the teaching in the other subjects. The students each come for one class period a day, and one day each week is dedicated to each of the four subjects. Fridays are left more open, and we have often used that time for writing articles for a school newsletter or for reading and writing poetry. The most difficult restrictions of the class for me are a very specific imposed 
curriculum and the related expectation that I teach in order to prepare students for frequent tests. The most powerful opportunity is that of working daily with small groups of students.

I bring to this work my experience studying the development of learners' ideas with Eleanor Duckworth $(1973,2006)$ through taking her course, "Teaching and Learning," at Harvard in 1983. Through that study, I developed the skill of engaging learners in order to reveal and develop their ideas. I see this skill as crucial to my work as a teacher. Two years after this coursework, in the context of the teacher research group, "Educators' Forum," I documented my efforts as a teacher to invite and develop students' ideas in a school context. Educators' Forum (led by Claryce Evans, [Evans et al. 1981]) was a group of educators in which each person focused on a question to pursue in her practice. We met every 2 weeks, each meeting being largely devoted to two or three people presenting the ideas, writing, and accounts of classroom events that were relevant to their questions, followed by comments and discussion from the group. We also gave some time to helping each person define her question as it evolved and to discussing ways of gathering information about it. There was a wonderful atmosphere of trust, close listening, and careful thought in these meetings, and we became very involved in each other's questions and pursuits.

My own question emerged most directly from my experience with the students I work with, but it is certainly not specific to my students, or to students with low test scores or grades, or to a certain school or locality. It comes from what I see as a radical disengagement of many students from classroom learning. How do I, within both the limits and the opportunities of my teaching situation, find points of connection between my students and the subjects that I teach? How can I help to engage their inner attention?

\section{Math and Metaphor}

At the beginning of the year, the freshman science classes were working on conversions in the metric system. The objective was to teach students the names of units of measurement and also to do these conversions on paper-to change meters into decimeters, for example. There was a chart in the textbook which defined each unit of measurement based on the basic unit-for example, a centimeter is $1 / 100$ of a meter, etc.

It was not at all clear to me how to try to teach this. My job, as it had been defined for me, was to follow the established class curriculum and somehow help these students pass their classes. The metric system conversions were the center of this science unit, but there was tremendous resistance from students to this subject. As I asked my groups of students some questions and saw some of the work they had done, I began to see that some very complicated ideas were masked by the simplelooking chart. Some kids were converting meters to milligrams or deciliters to kilometers. If something called a centimeter can be turned into things called millimeters, why can't it also be turned into milligrams? This question makes much sense if these are to you simply words in a chart that have no deeper meaning than 
the page they are on. The same question could be asked about the fractions next to the words. If 1000 is next to the word millimeter, even though it has a line over it with a one on top, wouldn't this word mean something bigger than one meter, which is only a single digit? This is, in fact, what some of my students did say. It is when we let the centigrams go and began to pursue their ideas about fractions that the story becomes interesting.

My clearest notes on this day involve a group of four students. We were all sitting around a table, having just been talking about the metric units. None of them had been very involved, but I had glimpsed the surface of some interesting ideas about fractions. I wrote down 1/3, 1/2, 1/4, and asked which one was largest. Seth said 1/4, then $1 / 3$, then $1 / 2$ because 4 is largest, then 3 , then 2 . The others agreed. I asked them to imagine something that we could divide so that we would each have a piece of it, and then to draw it. Tony and I both drew rectangles and said they were cakes. Seth drew a pizza and began to decorate it with various toppings, and Joe did not draw anything, saying that we could divide the piece of paper in front of him. Annie did not draw anything either-she is very quiet, seldom speaking or participating in class-but sat watching.

Tony had made lines inside his rectangle to divide it into five fairly equal pieces. I asked him how much of the whole cake one of the pieces was, and he said, "five...no...one fifth...no...one." He did not seem satisfied with this, but Seth interceded to say, "If you took one away, it would be one-fourth." I asked him what would be one-fourth, and he said, "The piece. You'd have one piece and four left over so it would be one-fourth."

Someone-either Joe or Tony-commented that it was the cake left over that would be one-fourth, because there were four pieces. Seth answered that it would have to be the piece, "it's one-fourth." Marguerite, who had been listening from a nearby table, came over then and tried to explain to the group that it wasn't fourths at all, it was fifths. Seth, firm in his theory, disagreed: "It's fifths when they're all together, but when you take one away, it's fourths." "What about when you take two away?" I asked. He started to say that it was two-fourths and then corrected himself: "No, you can have thirds, they'd be two thirds." Joe, during this discussion, had been neatly folding and tearing his paper into eight similar-sized pieces. Marguerite took five of these and tried to explain again, this time directly to Seth, that it would stay fifths because there were five pieces.

One of the striking things about this discussion for me was that throughout it nobody asked me if they were right. I was trying to make quick notes about what was happening and, unfortunately, missed Seth's response to this second explanation. I'm not sure he said anything. I am sure that he wasn't convinced, because he still held on to his theory when we came back to the subject on subsequent days. I asked Annie what she thought, and she looked at me and shrugged. Tony thought that Marguerite was right but couldn't say why. Joe seemed to be thinking, folding and tearing up another sheet of paper.

I remember being confused during some of this class. As I tried to make sense of the students' ideas, I was having to rethink the relationships we were working with. Seth could explain a lot with his theory. (I realized that he was trying to make the visible number of objects correspond with the fraction symbol-if he imagines 
taking one of four pieces of a pizza, he sees it as one-third so that the one and the three in the fraction symbol can actually be seen in the grouping of objects.) Meanwhile, Joe had torn a piece of paper into fourths and put the pieces together in front of him on the table. I wish now that I had asked him what he was doing, but instead I said that we should gather up the eight pieces he had torn before and put them together. We did, and they made a whole the same size as the whole made of fourths. We had been working with equal-sized pieces of the same whole, and I wanted to move to different-sized pieces of equal-sized wholes. I asked which would be bigger, one-fourth or one-eighth. This was not the best thing to do for Seth, who said something about there not being any eighths-I assume because, though he thought there were eighths when all eight pieces were together, according to his thinking, when you take one away it becomes one-seventh. But Joe picked up a piece from each group, one in each hand, and looked at them thoughtfully. There are sometimes words or gestures of students that stay in my memory, and this is one of them. He said the larger piece must be the eighth. (He had agreed with Seth, at the beginning of the discussion, when Seth had said that $1 / 4$ is bigger than $1 / 3$ because 4 is bigger than three.) But then he stopped in confusion-he saw that this larger piece clearly came from the group of four. I think this idea of different sizes is what he had been thinking about as he ripped up paper. He looked at me after a moment and said, "No. These (the fourths) are bigger. But the eighths are bigger in pieces." The first part of that statement made it clear to me that he meant "in number of pieces."

We continued this study a few days later. As a class, we went into the cafeteria and started to look for things "divided into equal parts." This was my phrase and the only instruction, along with the suggestion that they could also look out of the windows to find things. I had not planned to spend too much time with this, but rather to move from it into continuing the discussion we had begun before. We began to look, with some people walking around the room and others going to the windows. Someone pointed out the table benches, which are made of two equal pieces, someone else the tables, which are similar. Tony, at the window, noticed windows on the buildings outside. I pointed out the walls, which are made of samesized bricks. Then, calling back and forth to each other, they noticed the floor, the ceiling, the lights, cabinet doors, lines on a radiator, tracks of a cabinet door, somebody's shirt, the beads of an earring. From the windows, they saw divided doors and bricks of outside buildings, a row of slanted parking spaces, the sidewalk, bus windows, stripes on a flag, all kinds of window panes, the pattern on a truck, a row of poles with equal space between them.

Finally, I asked each person to choose one of the things they had seen and point it out to the group. I had been thinking of "equal parts" as one solid thing, like the wall or a cake, divided equally. In other words, I was thinking of the parts as being right next to each other. Some students pointed out things that accorded with this interpretation. Some, however, called our attention to things that were equal-like the windows of a building - but not next to each other or part of a continuous whole. One girl thought "equal parts" meant one object with some of its sides equal in length to its other sides - a rectangular picture, for example. One or two people pointed out an object with parts next to each other but not equal in size. 
I hadn't anticipated either how much they would find or the different interpretations of the phrase, "equal parts." We discussed these, illustrating with the objects that we had noticed in the room or from the window. I realized that everyone had understood that something about what they were looking for had to be the same (equal) and something also had to be different (parts). Either it had to be one and the same object with different, not necessarily equal (in area or volume) parts inside it, or it had to be an object with different sides of the same length, or objects identical but separate from each other, or one object divided into identical pieces. Though I had not mentioned anything besides "equal parts" during this class, at some point Daniel brought up fractions to say that with fractions, "the pieces don't have to be next to each other." This was not how I had been thinking about it, but he was, of course, absolutely right.

Two weeks later, I was again in the cafeteria with this group. The basic math classes were then involved in a unit on fractions, and though the textbook centered on how to do operations - how to add, subtract, multiply, and divide fractions-we were still talking about thirds and fourths, pieces and wholes, and illustrating with the tiles on the floor. Seth was still holding fast to his theory. But what stands out to me in this class concerns Annie, who finally, on this day, became involved. She spoke up suddenly, agreeing with Seth's idea, explaining, while pointing to the tiles, that if you had six and you chose one piece, it would be one-fifth, and if you chose two it would be two-fourths, and so on. We came back to talking about this later while the others were doing something else. I asked her, marking off three adjacent tiles with my hands, how much she would take away if she took one tile. She looked at the tiles and answered, "one half." "And," I said, "if you were to divide all of this (the three tiles) in half between us, where would you divide it?" She paused, and started to point to a line between two of the tiles (Fig. 1) but then slowly moved her finger to the middle tile and drew it downward in a line (Fig. 2). Looking at me, she said, "It's confusing. There's two halfs." I think that she meant, not that there are two pieces, but that there are two different ideas of one half-the idea that fits with the "one over there, two over here equals one-half" theory, and the one that she knew from a lot of experience with dividing things in half. The bell had rung, but she sat there for a few minutes, staring at the floor.

To extend these observations with a different facet of math work, I focus on Mary, a student with whom I often work individually. She came in to me one day saying that she wanted to recite the multiplication tables. We had been doing work that had been confusing to her, and I think she wanted to do something that she felt somehow to be contained and that she felt more sure of. She started reciting, always getting through five by reciting from memory as far as I could tell-for example, $3 \times 1=3,3 \times 2=6$ and so on to $3 \times 5=15$. When she got past five, she started using her fingers, starting with where she left off at five. For example, if she got to

Fig. 1 Three horizontally adjacent tiles with arrow to line

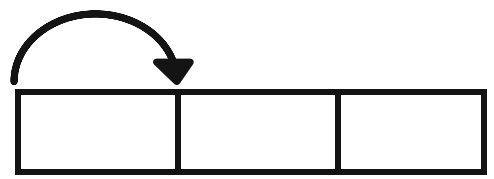


Fig. 2 Three horizontally adjacent tiles with arrow to the middle of the center tile

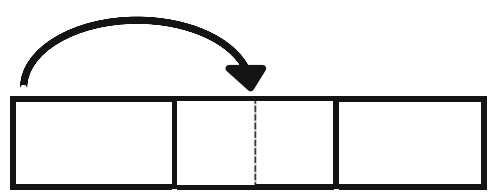

$3 \times 5=15$, she would continue with $3 \times 6$ by counting on her fingers $16,17,18$, and then 19, 20, 21 for $3 \times 7$, etc. going up to ten. I did not intervene until she got to $7 \times 6$, saying it equaled 41 . She had said a few moments before that $6 \times 7=42$, and I asked her if the different orders of the numbers should lead to different answers. She said that the two answers should be the same, but insisted that $7 \times 6=41$ because $7 \times 5=35$ "and then you add six more." I asked if it mattered which number you added, 7 or 6 , and she said yes, if you added 7 it would be 42. "How do you know it isn't 42?" "Because it's 41." She then added 6 to 35 again out loud and got 41, then did $6 \times 7-6 \times 1,6 \times 2,6 \times 3$, etc. - and got 42 . She knew that there was a problem with having two answers, but I am not sure what she thought the problem was. She didn't know what to do about it, saying quietly, "They aren't the same...but they have to be...but they aren't...but they have to be..." I was reminded, hearing this quiet, rhythmic chant, of a child, Jenny, who I had once worked with on the question of how someone would see an object that Jenny was seeing from a different position than Jenny in the room. She, like Mary, was trying to bring together seemingly conflicting ideas, and a rhythm came from her also as, thinking deeply, she said, "The same...but different...the same... but different...the same...but different...he would see it the same but different as me." She was trying to reconcile the ideas that the object was the same, but it would look different. Mary's rhythm impressed me as also coming from careful thought.

I brought out some triangular pieces of plastic and asked if she could use them to show how much $7 \times 6$ equals. She hesitated and then took 7 pieces, laid them out, and then laid 6 out underneath (Fig. 3):

I asked her to count them, and she said that there were 13. She went through her counting system again on her fingers, arrived at 41, and laid 41 pieces in random order on the table. What I was seeing was that she did not see multiplication in terms of groups, of combining 7 groups of 6 or 6 groups of 7 . Though she was basically adding groups as she counted on her fingers, I don't know if she saw that as what she was doing. I asked her to try to use the triangles to figure out $3 \times 4$. She did the same thing that she'd done before (Fig. 4):

But then she looked hard at what she had and added 5 more so that she had 2 groups of 6 . I think she knew that $3 \times 4$ was 12 -she still did not lay it out in 3 groups of 4 or 4 groups or 3-but then she sat thinking, looking at these groups of 6 . And then she said. "Wait a minute, you have to add higher numbers to get the same

Fig. 3 Two rows of triangles, 7 on top, 6 underneath

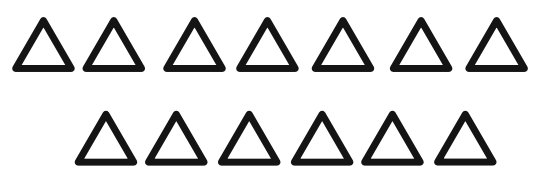


Fig. 4 Two rows of triangles, 3

on top, 4 underneath

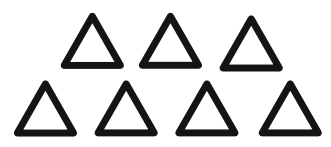

answer you get with lower numbers in the times tables." She had been looking at the two rows of 6 and realizing that adding them gave the same number as $3 \times 4$, which are lower numbers than 6 . Her statement showed her just beginning to see a relationship between multiplication and addition. My guess is that before she had been thinking of the "times tables" as some kind of self-contained entity which did not touch other things you could do with numbers.

On another day, Mary and I worked on a subtraction worksheet that she had to complete for her math class. She was working with four and five digit numbers. With the problems already laid out for her (one number on top of the other), she did them sometimes by borrowing, but sometimes rather than borrow she'd subtract the top digit from the one below it. When I pointed that out, she thought she should change what she was doing, but she did not seem to understand why you should borrow rather than just switching around the numbers (maybe borrowing seemed to her like just another way of switching around numbers to make it work). When she did word problems (like "subtract 4111 from 20005"), she wrote the number that she saw first on the top and the second one below it:

$$
\begin{array}{cc} 
& 4111 \\
& \\
\text { Her answer: } & 20005 \\
\hline 21115
\end{array}
$$

When I asked, she said that bringing the 5 down like this is like bringing the 4 down here:

$$
\begin{array}{r}
45235 \\
-5113 \\
\hline 40122
\end{array}
$$

I asked at some point if she thought it mattered which number was on top and which on the bottom when she subtracted. "I don't know," she answered. "I just subtract."

I think she was seeing large (4 or 5 digit) numbers as collections of individual numbers rather than thinking of them as one whole. She was not seeing them as numbers holding place values. 4111 was not 4 thousand 1 hundred and eleven, but four one one one. It did not seem to make much difference to her which numbers she subtracted from which other numbers, as long as she subtracted between the two sets of numbers rather than within them. She was manipulating numbers by trying to use rules that were basically meaningless to her.

In addition to math, my classes were following the English curriculum focused on the figures of speech. Mostly what the kids are asked to do on tests is to define "simile," "metaphor," "personification," etc., and to pick out figures of speech in literature. Frank could state parts of the textbook definition of metaphor, but in trying to illustrate it in writing, he wrote, "The fire siren is loud." This is similar to 
sentences that students wrote when trying to apply the definition of simile-for example, "I like the football game." They tried to make as much sense as they could of a definition by focusing on a word in it (a metaphor says that one thing "is" another, or a simile has to use "like" or "as").

The class that captured most students' interest was one in which I gave them lists of about 60 similes and metaphors (descriptive sentences), had them each pick one they wanted to write about, and then asked them to work out and describe in writing, possibly as a poem with the simile/metaphor as the first line, what they thought the sentence was describing. Much of what they wrote was striking in its capturing of the metaphors - the feeling and nuances of them as well as the explicit comparison. Frank, who had been confused and resistant before, worked on this for the full class and wrote the following complete poem, building on one of the metaphors from the list.

metaphor he chose: Soft white feathers, the snow fell gently to the earth.

his writing: $\quad$ Little feathers coming down to the earth as quiet as can be making no sound at all. They look like little designs that can only be made by themselves.

No one bothers them at all. Just make their way.

Here comes snow.

He did not yet understand the formal definition of "metaphor," but he understood this metaphor at its fullest.

\section{Matching Shadows}

I believe that often the ways in which we mold subject matter for students turns it, for them, into empty shadows. It becomes at best an outline of something that is real. But the problem goes even beyond that. You see a shadow of a tree and it has some meaning for you if you know it is a shadow of a tree-it has a connection to the tree. In much of the established curriculum that I have seen, this connection is ignored. We are left with shadows that shadow nothing, having lost their connection to the substance of the world. The critical point is that we are presenting students with piles of symbols-numbers, words, statements, all of them are symbols. But the symbols are often meaningless to them-literally without meaning.

Somewhere in school, students see the symbol for one-half and are told that this one-over-two-with-a-line-between-them means one of two equal parts. At that point, we often expect them to "know" this, either to fit their own varied ideas about this complex subject into the symbols that we have given them or to leave these ideas outside the classroom door. Because inside the classroom and the textbooks, the symbols are often all that there is left. I remember a math homework paper that a student, Julia, showed me recently. It had come from the textbook and dealt with multiplication and division of fractions, a large section of problems for each. I looked over the work and saw that all of her answers were correct on these problems. She had given what she was asked for. But there was a very small section above these-four or five problems-which asked her to say whether $1 / 3$ was greater than, less than, or equal to $1,1 / 4$ to $5 / 4,1 / 2$ to $1 / 6$, etc. None of these 
answers were correct. I thought possibly she had mixed up the signs for greater than, less than, and equal to, though I could see no pattern to indicate this in her answers. I asked her, and she said no, she knew what those signs were, she just didn't understand that part. "It doesn't matter, though", she said. "Those are only a few out of the fifty problems." What possible meaning could all that work have had for her, when she "didn't understand" that $1 / 3$ is less than 1 ? I am sure that she actually understood much of what is underneath those symbols. She knew that one of three parts of a cake would be less than the whole. She knew that one of two parts would be bigger than one of three parts if the whole was the same size. What she knew was inaccessible to her in the form in which it was being asked for.

This is very similar to Mary's subtraction work. Julia's answers involving operations with fractions were "right", and Mary's subtraction answers were "wrong," but that does not make the slightest difference. Both were manipulating meaningless symbols in ways they had been told to manipulate them. Mary's "mistakes" make some sense-if you can bring down an extra digit from the top number, why not from the bottom one? If you can bring it down from the left, why not from the right? And Seth's theory is a wonderful attempt to make those fractions mean something, to attach those numbers to something that he could clearly see them as representing. Fourths means four pieces because there are actually four there (Fig. 5).

But if you take one away, it becomes $1 / 3$ (Fig. 6).

What the 1 and the 3 are representing is clear, and the line also represents something visible to him-a separation. Later I saw that when Seth was working with shaded parts of a whole that remained intact — which is how the textbooks that I have seen explain fractions-he would say that one of three pieces equals $1 / 3$, two of four equals 2/4, etc. (Fig. 7).

The pieces in this case are all still together-he could see the three or four. But when the pieces are separated or he imagines them as separated and the three becomes one and two, how could that piece still be 1/3? Similarly, if you know that five things equals 5 , how is it that this same 5 equals 50 when you see 58 , or five thousand when you see 5618, or five-hundredths when you see .25? If you are used to thinking about the word green as meaning a certain color, how does it make sense that, as Robert Frost says in a poem, "Nature's first green is gold"? How can green be gold? A student asked this penetrating question, which, as can be true of all of these questions, eventually led her more deeply into the subject-poem in this case-that it came from.

In each of these examples-the fraction work, the issue of place value raised through subtracting multi-digit numbers, the question raised by figurative language-I believe the specific difficulty comes from encountering a symbol

Fig. 5 Four adjacent rectangles in a vertical line

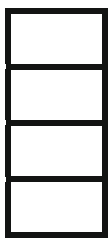


Fig. 6 Four rectangles in a vertical line with space between top one and bottom three

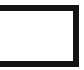

Fig. 7 Two circles, one divided into three equal parts with one shaded, one divided into four with two shaded
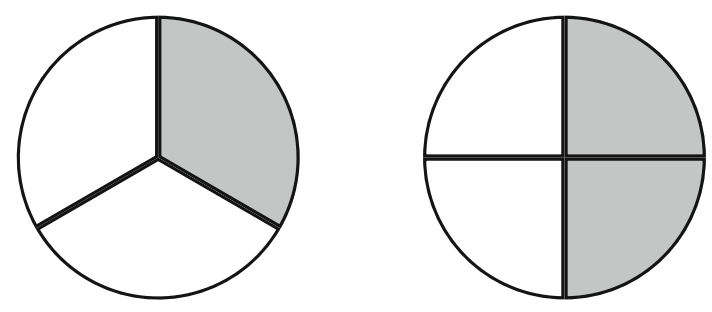

system that is partially familiar to the student but has increased in its complexity. Students learn the system of whole numbers-an achievement that is itself hard won-and then with fractions they encounter those same numbers within a more complex system of symbols. Moreover, on the surface, the additional meaning assigned to fraction symbols can seem to conflict with previous knowledge. For example, the student knows that 4 is more than 3 , but having a 4 on the bottom (1/4) means a smaller piece than having a 3 on the bottom (1/3). The system that makes sense of both whole number and fraction values together is complex and requires an extension of understanding. So does the meaning of place value. Similarly, students contend with an increase of complexity when they encounter figurative language. Familiar words used in figurative forms add layers of significance and vastly increase the possibilities for meaning.

These junctures-at which the potential for meaning increases—are fascinating to me as a teacher. It is true that they are also potential stumbling blocks, but this is because they are part of the depth of the subject matter and therefore are the places at which students can learn the most. If given the opportunity to think through the new relationships they are encountering, students can surge forward in their understanding and enlarge the realm of their intellectual action from that point forward.

How do we give students this opportunity? In the course of the work previously described, Joe divided two same-sized pieces of paper into four and eight pieces. He did this on his own, after I had probed the students' ideas about what those fraction symbols represent. He did it to isolate a question, to explore his own idea. After looking from the bigger piece (1/4) to the smaller piece (1/8), back and forth, studying them, he resolved his question by looking directly at me and saying with conviction, "No. These (the fourths) are bigger. But the eighths are bigger in pieces." He gained insight into the relationships being represented and saw that the denominator represented not size but number of pieces. He also saw that in the case of the denominator, size and number have an inverse relationship. 
In a similar example, Annie developed her ideas after first having accepted Seth's theory about the fraction symbols. Marking off three tiles on the floor, I asked her where $1 / 2$ would be, trying to give her access to her own closely-held knowledge. She began to answer in accordance with Seth's idea and then realized that it conflicted with her own belief about the meaning of 1/2. "It's confusing," she said. "There's two halfs." That conflict moved her to counter Seth's theory, staring at the tiles on the floor.

A reader might wonder why I didn't just explain the aspects of fractions that confused the students when their confusion became clear to me. But they had heard corrections and explanations many times in their school careers. Their beliefswhat made sense to them-existed quite apart from the statements that they had heard in class or read in a textbook about how these numbers worked. They needed to have the chance to enlist and use their own ideas in order to figure out how to embrace the relationships being symbolized.

The question for educators is how to create situations that will give students both access to their current ideas and the opportunity to develop those ideas further. The students will then be able to arrive at the conventional symbols having developed knowledge of their significance. When attached to and understood in terms of what a person already knows about the world, symbols can enrich that knowledge. The degree of this attachment is also the depth of their meaning. But I have so many times seen students, when doing homework in science or history-almost completely textbook subjects in my school-, looking at words in a chapter review question, then going back through the chapter until they find the same words (usually italicized), and then writing that sentence on the paper. Can it give them anything at all, this matching of words? The laws of nature simply will not give us the shadow without the tree.

Yet this is often how we give subject matter to students. And this brings me back to my question about their engagement in classroom learning. I believe that part-a critical part - of their withdrawal comes from the fact that students are often asked to learn about subject matter presented in forms which are to them profoundly meaningless. We give them arrangements of disembodied shadows. There is nothing for them to connect to, and their inner attention, their vitality, is not called forth. They pull it away, and match those shadows with their own.

The students whom I have described certainly did not dance around with excitement at learning about math or metaphor. But this is not (primarily) what I am looking for. Or rather, I look for it in the form of their active thought. And I believe that I see it sometimes - in the rhythm of Mary's words as she puzzled over $7 \times 6$ versus $6 \times 7$, or Joe's looking from the big piece of paper to the little one, in Seth's trying to explain his own theory, Frank's quiet concentration on his poem, or Annie's stare at the floor. 


\section{The Roadway}

I went to a zoo recently with some friends, one of whom was a three-year-old boy. It was a tropical zoo, full of all kinds of exotic animals, confined but not caged. A road ran through it, and many people moved along this walkway, pausing to look at the animals. This boy and I paired off for some of the time and often found ourselves far behind the others. When his interest was caught, it was firmly held. And we so often fell behind because what intrigued him was not only the animals. He was stopped by things not accounted for by the roadway, things that everyone else on that road (and this would have included me if it had not been for him) were passing as they watched for the next presented sight. He stopped as he noticed a deep hole in a low stone wall bordering the road, and he put his hand into it, slowly moving it around, feeling for what was inside. A penny shining in the sun caught him next, and he paused to look at it and move it around with his foot. At another time, he turned off the road into a mass of plants and bushes, fingering the huge, tropical leaves. He hesitated before nails and large bolts and tried to push them, and when we stopped to sit down, ran his hands along the winding cracks in the wooden table. There were a lot of voices calling for his attention that day-"Look, there's a huge fish!", "Look at the white tiger!" — and he looked, often with excitement. But it was clear, as he hesitated in front of certain animals for a while after others had moved away, and as he was continually caught up by all those things beyond the roadway, that for him the most arresting of those voices was his own.

I often find myself in the dilemma of whether to stray, with my students, from the established curriculum. Frank, I am sure, with some time, with some more reading, writing, and working through of metaphors, will come to understand that textbook definition. But partly because we do not have that time between tests, the choice as it often appears to me is either to drill students so they can write down the right words, or to turn away from this concern altogether. This decision is not easy. Those test scores follow students. They are judged by their scores and, tragically, often judge themselves by them also. Often what I decide to do is to pause on the established road to explore a complexity in some depth, led by the students' varied ideas. The previous descriptions were examples of this to some degree-they were not stories of my trying to explain metric system conversions or how to multiply fractions. I did see in the work we did, however, a fairly clear connection to that curriculum.

Not long ago, confronted by statements about how "boring" science is, about how it is all "a boring book," I looked, with some distress, at the students in front of me. What to do about this has been one of my biggest problems. I don't remember what led to the talk about science that day-we were not working on it. As a feeble attempt to make a point, I held my pen up, dropped it on the table, and said that I thought there was science in that. There was some interest. Did I mean in the pen? In the table? Frank said. "She means gravity." Maria disagreed, saying that gravity makes things float. I asked her what things, and she said "like balloons". There was quite a variety of ideas on this subject. In the process of articulating them, we first got involved in throwing things (pens, balls of paper, paper clips) up in the air, 
watching as they moved upward and fell back down-Cathy had wondered whether gravity is what makes things go up. After a while, I asked her what made them stop going up and come back down. She said she didn't know, but Maria explained again that there is no gravity in the things we were throwing-they don't float. It became clear later that she thought that gravity was inside an object itself, making it float. Leslie said that gravity was outside the things, making them float. Someone countered this with the idea that the gravity inside things makes them fall, and the faster they fall, the more gravity they have. I think it was Maria who said, "No, how fast they fall depends on how much they weigh." We went from this to dropping two things together to see how fast they fell. After an unclear first contest between a paper clip and a crumpled piece of paper, everyone but the dropper followed Cathy in lining their eyes up with the table. There was disagreement about the second result. Some said the paper and the clip hit the table together, others said the clip hit first. But there was also disagreement about which one weighed more. Everyone agreed that a quarter weighed more than the paper clip, but there was still a difference of opinion about the quarter hitting first versus both objects hitting at the same time. There was some surprise that there was not a clearer difference. There was a clear difference between a crumpled piece of paper and a flat one, which made Frank say that paper must weigh more when it's crumpled. I think that Maria agreed with this statement, but someone else disagreed, saying that air slowed the flat one down. I don't remember exactly how we got to talking about cooked rice and dry rice. Frank brought it up (I was very confused as to why at the time). He ended up saying that he thought cooked rice would weigh more and fall faster. This is where the discussion was ended by the bell. The students left the room with an interest in investigating this subject further.

As I thought about Frank's statements afterward, I began to understand why he was talking about rice. The pieces of paper started out identical, but one was then crumpled. A grain of cooked rice starts out as a grain of raw rice, but then it is cooked and changed to something different than another grain of raw rice. Each pair of objects starts out absolutely identical, and then one changes. What a comparison! Frank, thinking about how a piece of paper changes when it is crumpled, was struggling with the idea-again this theme-of what is different and what stays the same.

I had the chance recently, as a result of a week of lengthened class periods, to work with Mary for a full hour. I asked her if she'd like to work with the math we'd been doing or with a poem. She hesitated and then decided on a poem. I gave her a book from which to choose one, thinking that she might be tired of the one that we had been coming back to at various times during the semester. She said she'd rather do that one, however ("The Lake Isle of Innisfree" by W. B. Yeats), and searched for her copy in her bag. She couldn't find it, I found mine, and we began.

I had been thinking that we would focus on a question that Mary had asked when we had last worked on this poem. "How can he be at a lake and on a city road at the same time? Is there a lake in the city?" But we started, as we always do, with Mary reading the poem aloud. She read it once, and then again, and as was true even of the first stumbling times that she had read this poem weeks before, her words 
became increasingly quiet and slow as the rhythm found its way into her voice. And then she read it a third time,

I will arise and go now, and go to Innisfree,

And a small cabin build there, of clay and wattles made:

Nine bean-rows will I have there. a hive for the honey-bee,

And live alone in the bee-loud glade.

And I shall have some peace there, for peace comes dropping slow,

Dropping from the veils of the morning to where the cricket sings;

There midnight's all a glimmer, and noon a purple glow,

And evening full of the linnet's wings.

I will arise and go now, for always night and day

I hear lake water lapping with low sounds by the shore;

As I stand on the roadway, or on the pavements grey,

I hear it in the deep heart's core.

It is difficult to capture what happened next. Words began to spill out of her, connecting images in the poem to things that she had heard and seen and felt before. "There's a cabin like a little house with bees buzzing and it's quiet like it is when it's late at night or early in the morning and you're by yourself and you hear birds when they fly... and the purple glow is like it is in my room when the sun's about to come up... and he is in the quiet and hearing his heart beating...sometimes you can hear your heart and feel it beating if you're in bed or you stand still without noise, and he hears the lake water too... and I like the word glimmer!"

When I could get my breath, I asked Mary what she liked about the word glimmer. She said that it reminded her of the stars, that they glimmer, and I suggested that she write a poem about it. She did, entitling it, " I Like the Word Glimmer." We then stapled the Yeats poem into her notebook and stapled her poem beneath it. She closed the book and-in one of those unforgettable gestures-held it against her chest for a few seconds with her arms over it.

She then began to talk about the stars, about how she looks at them sometimes when she is walking, and it seems as if they move. I asked if they really move and she said, "No, it's that there's so many of them-you think they're moving, but you're really seeing different stars." I asked her if the moon ever looked like it was moving that way, saying that sometimes it looks that way to me. "Yes," she said, but that's us moving, because there's only one moon. It's different with the stars." In answer to my question about whether she wanted to add something about the stars moving to her poem, she said, "No...I'll write another poem about that." I suggested that she write down what she noticed about the stars in the notebook with the poems to give her more things to write poems about. She agreed and wrote a few sentences about how she sees them move, but it's really more stars. We agreed that we would both look for them in the sky that night.

The bell rang, and she rose to go. There is a large partition in the classroom, screening out both the door and the windows into the hall. Mary disappeared behind this on her way to the door, and her voice called across it, against the background of the voices in the hall, "Don't forget to look at the sky." 
One final note: After a number of days, Seth moved beyond his initial theory about fractions.

\section{Addendum}

I wrote "Dancing in the Hall" as a beginning teacher in 1986. Its central question continues to be as important for me today as it was when it was first written. How do we, as teachers, help students to call forth the vitality of their own minds? This complex and fascinating question leads us to investigate the nature of learning and the act of making meaning. It invites us into the profound challenge of entering the perspectives of the students whom we teach, of seeing the sense of those perspectives in order to encourage our students to act in behalf of their own learning - to recognize and build upon their own points of view.

Over the years, from my perspective as urban public high school teacher, curriculum developer, professor of education, and researcher of learning, I have seen changes that make me hopeful. Varied efforts have had as their goal the movement away from rote learning and toward students actively making sense of subject matter and articulating their thinking. Organizations that make primary source materials accessible to teachers (Critical Explorers, Facing History and Ourselves, Primary Source), innovations in teaching practice and classroom discourse (Mayer 2012), alternative forms of assessment that allow students to demonstrate the development of their ideas ([Seidel 1998], see also Turning Points publications), and school reform centered on curriculum structured to promote authentic investigations (Expeditionary Learning) are all examples. There has been progress in describing and including diverse cultural, linguistic, and gender experiences. (See the work of Cheche Konnen [Conant et al. (Eds.) 2001], the Rethinking Schools publications, Lisa Delpit's work [Delpit 1995, 2002], James Sears' work [Sears 1991], and Carol Lee's work on literacy [Lee 2007]). Researchers are countering the notion of IQ tests as comprehensive predictors of achievement and entertaining more diverse conceptions of learning and human intelligence (Duckworth 2006; Gardner 2006; Gould 1996).

However, even with these developments, we continue to struggle with how to enlist the capacities of our students' minds. In particular, the equating of higher intellectual expectations of students with high-stakes testing is a significant problem. These tests have created enormous pressure on students, teachers, and schools, most often without yielding the promised return of higher quality or more equitable education. On the contrary, schools are now spending large proportions of instructional time on test preparation strategies and on the testing itself.

I have often wondered, over the years since "Dancing in the Hall" was first written, what it is that makes us so vulnerable as a profession-what it is that allows us to fall victim to concerns or policies that are counter to our hard-won professional knowledge. In the urban public system where I taught throughout those years, I saw programs or structures that were most effective continuously being cut or reconstituted. We have endured a pattern of disconnection between student/community realities and education policy decisions on both the community and national 
levels. This disconnection is particularly evident in school systems whose students contend with racism and poverty, and leads us to question, as Asa Hilliard did, the will of our society to educate all children (Hilliard 1991). But there is another weakening force that exists side by side with this possible failure of will. Even within our efforts toward equitable and effective education, and even within our most affluent and "high-achieving" schools, we as a profession are still largely confined within a view of learning that alienates us from our primary resource: the capacity of the human mind, the learner's potential as a thinker. We have yet to release ourselves from the grip of a narrowed view of the nature of learning. This, I think, is the core of our vulnerability. We are not seeing what is right in front of us and what could be our greatest strength: the largeness of the learning potential that we carry as human beings.

Seventy years ago, Max Wertheimer's posthumous 1945 work, Productive Thinking, brought into focus the effect on education of commonly held assumptions about learning. He writes, "For there are basically different ideas about what thinking is, each with serious consequences for behavior, for education...How teachers act, how a subject matter is taught, how textbooks are written, all this is widely determined by two traditional views about the nature of thinking: the view of traditional logic and the view of association theory" (Wertheimer 1982, p. 2).

Traditional logic as a general description of thinking is, in Wertheimer's words, "barren." He continues, "...one has, then, a series of correct operations, but the sense of the process and what was vital, forceful, creative in it seems to have evaporated in the formulations" (p.10). In association theory, "the old idea of repetition, in contiguity, is still the central feature" (p. 8). He questions "whether the way in which [these views] interpret thinking does not cause serious hindrance, an actual impairment of genuine abilities" and implies that the prevailing views about the nature of thinking are limiting our beliefs about human potential and therefore limiting what educators put into practice (p. 2).

The essential point for my purposes here is that restrictive views of learning still have a hold on the public consciousness today. These views, each in its own way, put forward a conception of learning as a repetition of already-formed relations. They are allowing us to teach as if students can learn complex relations simply by being told. Each calls for didactic teaching - a delivery of the correct connection or logic_-rather than teaching that asks learners to engage their own experiences and current ideas in creating new knowledge. These views therefore have, according to Wertheimer, "perhaps not touched the core of the problem at all" (p. 2).

Jean Piaget, writing at the same time as Wertheimer, addressed "the core of the problem" by reconceiving the nature of human thought. In his astonishing body of work, accomplished with his colleague, Barbel Inhelder, he manages to follow the living movement of the human mind (Piaget 1966, 1986). Beginning his career as a zoologist, he came to his theory through studying the development of living beings (Piaget 1980). His theory is consonant with the organic nature of growth; each movement of learning is an act of creation on the part of the learner.

Eleanor Duckworth, collaborator and scholar of Piaget and Inhelder, describes this core idea in their work: "Meaning is not given to us in our encounters; it is given by us, each in our own way, according to how our understanding is currently 
organized" (2006, p. 113). Learning is, in other words, an active enterprise on the part of the learner, who builds his or her current ideas into new understanding. It is this conviction about the integrity of each mind inside of its own growth process that Duckworth has elaborated in her work. She has explored the significance of this view for the understanding of learning and for the field of education $(2001,2006)$. It has led her to her claim that "...intelligence is a matter of the having of wonderful ideas. In other words, it is a creative affair" (Duckworth 2006, p. 12). The implications of this view for the democratization of educational practice are profound. Every mind, every person, creates a unique pathway of intelligent thought.

In contrast, we have absorbed a language of limits in our society and in our schools that relies on our assumption that intelligence and ability can be measured on a linear scale. This scale, as Stephen Jay Gould illustrates, has served, both purposefully and by default, to subjugate rather than to realize human potentialboth individual potential and that of entire human groups (Gould 1996). We describe students as "more" or "less" intelligent, as "slow" or "gifted" or "learning-disabled." While the education field is currently improving to some degree on the specificity in describing students and their work, these general adjectives still hold sway.

Perhaps the most striking finding that I recount in "Dancing in the Hall" is how close the students were to being intellectually engaged, at every moment-this very group of students who were failing their classes. We did not have to reach far. This is the "dancing" to which I refer, the students' energetic action in the hallway moved into the realm of the classroom. The classroom situations described were not dramatic or rich in resources. The subject matters were not particularly "high interest" or overtly fun or exciting. But that vitality was unmistakably present as the students brought the powers of their minds to bear on the question or material under study. What is notable in each description is the individual or group of students coming to care about the ideas they were working with. It came to matter to them what the fraction symbols were representing, or whether switching the order in multiplication could yield different results, or what a metaphor was able to express that a simple statement could not. Or perhaps it is more accurate to say that it mattered to them all along, mattered a great deal, mattered at least as much as what happened in the hall, but the students had ceased to experience their own interest because their beliefs were not engaged. Their own ideas were not engaged. Perhaps it is fair to say that any genuine encounter with the world will matter to them, will call forth their vital presences rather than their shadows.

As I observed the students in this study, sometimes their growing interest was clear in their words, sometimes in their actual work, sometimes most strikingly in their gestures. These gestures, highlighted in this paper, are still with me thirty years later as examples of students fully absorbed in working out conflicts that arose as they brought a theory or question of their own to bear on the study of a particular subject matter from which they had been previously alienated. In these gesturesJoe looking intently from one fractional piece to the other, Annie staring at the divisions made by tiles on the floor-I saw the return of their active minds. The 
perceived conflicts with which each student struggled moved the students into developing more adequate and accurate thinking about the subject under study.

This is what I have continued to see in the years since I wrote the paper. I still find these descriptions instructive both for the teaching practice that invited the students' acts of sense-making and for the curriculum implications in terms of structuring activities that invite students into the critical junctures in which a subject increases in complexity. The conflicts within their own thinking that they encounter at these junctures are like motors that propel their thinking further. I return to these descriptions often as reminders of what students can do, and what educators can do to reach for students' thought and to structure curriculum to encourage genuine acts of learning.

\section{Compliance with Ethical Standards}

Conflict of interest There is no conflict of interest in this study.

Open Access This article is distributed under the terms of the Creative Commons Attribution 4.0 International License (http://creativecommons.org/licenses/by/4.0/), which permits unrestricted use, distribution, and reproduction in any medium, provided you give appropriate credit to the original author(s) and the source, provide a link to the Creative Commons license, and indicate if changes were made.

\section{References}

Conant, F., Rosebery, A., Warren, B., \& Hudicourt-Barnes, J., (Eds.). (2001). The sound of drums. In E. MacIntyre, A. Rosebery, \& N. Gonzalez, (Eds.), Classroom diversity: Connecting curriculum to students' lives (pp. 51-60). Portsmouth: Heinemann.

Delpit, L. (1995). Other people's children. New York: The New Press.

Delpit, L. (2002). The skin that we speak. New York: The New Press.

Dewey, J. (1904). "The Relation of Theory to Practice in Education", originally in National society for the scientific study of education, Third yearbook. Part 1.

Duckworth, E. (1973). The having of wonderful ideas. In: M. Schwebel \& J. Raph (Eds.) Piaget in the classroom (pp. 258-277). New York: Basic Books; preprinted in Harvard educational review, 1972, 42, 217-231.

Duckworth, E. (Ed.). (2001). Tell me more: Listening to learners explain. New York: Teachers College Press.

Duckworth, E. (2006). "The having of wonderful ideas" and other essays on teaching and learning. New York: Teachers College Press. (Original work published in 1987).

Evans, C., Stubbs, M., Duckworth, E., \& Davis, C. (1981). Teacher-initiated research: Professional development for teachers and a method for designing research based on practice. Cambridge, MA: TERC Inc.

Gardner, H. (2006). Multiple intelligences: New horizons. New York: Basic Books. (Original work published in 1993).

Gould, S. J. (1996). The mismeasure of man. New York: Norton \& Co., Inc. (Original work published in 1981).

Hilliard, A. (1991). Do we have the will to educate all children? Educational Leadership, 4(1), 31-36.

Lee, C. (2007). Culture, literacy, and learning. New York: Teachers College Press.

Mayer, S. (2012). Classroom discourse and democracy: Making meanings together. New York: Peter Lang.

Piaget, J. (1966). The origins of intelligence in children (Margaret Cook, Trans.). New York: International Universities Press. (Original work published 1936). Retrieved January 1, 2018 from http://archive. org/details/originsofintelli017921mbp. 
Piaget, J. (1980). Adaptation and intelligence: Organic selection and phenocopy. Chicago: University of Chicago Press.

Piaget, J. (1986). The construction of reality in the child (M. Cook, Trans.). New York: Ballantine. (Original work published 1937).

Sears, J. (1991). Helping students to understand and accept sexual diversity. Educational Leadership, 4(1), 54-56.

Seidel, S. (1998). "Wondering to be done" in Assessing student learning: From grading to understanding. New York: Teachers College Press.

Wertheimer, M. (1982). Productive thinking. Chicago: The University of Chicago Press. (Original work published in 1945). 